\title{
What Should the Middle East and Ukraine Learn from the Balkans?
}

\begin{abstract}
The UN-endorsed doctrine known as "Responsibility to Protect" is one important outcome from the Balkans, honored more in the breach than the observance in the Middle East and Ukraine. There are others: leadership is important to starting, preventing, and ending wars; prevention can work, if undertaken early with adequate resources; ethnic partition likely will not; international contributions can be vital; neighborhood counts; power sharing and decentralization can help. Applying these lessons to the Middle East is difficult, not least because there are so many warring parties involved. Ukraine is far simpler and could prove negotiable, but only if Russia, the EU, and the United States are prepared to engage seriously to restore the country's sovereignty while allowing its regions a large measure of autonomy.
\end{abstract}

Keywords Responsibility to Protect - Leadership - Prevention • Partition $\cdot$ Power sharing $\cdot$ Decentralization

Many people think the Balkan experience bears on other situations, but of course they pick and choose the implications they prefer. Lessons learned are often lessons preferred. Bosnia haunts Syria. Those who favored intervention pointed to the "safe areas" in Bosnia and want something similar in Syria: safe areas, a no-fly zone, or humanitarian corridors. They forget that it was not the safe areas that succeeded in

(C) The Author(s) 2019

115

D. Serwer, From War to Peace in the Balkans, the Middle East

and Ukraine, Palgrave Critical Studies in Post-Conflict Recovery, https://doi.org/10.1007/978-3-030-02173-3_7 
Bosnia but rather the NATO bombing that occurred because of the failure of the Serbs to respect the safe areas. Those who want a political settlement in Syria point to the power-sharing arrangement forced on the Bosnians at Dayton. They forget that Dayton entailed major compromises as well as exceedingly slow and difficult implementation. Kosovo is often cited as a precedent for the independence of Kurdistan, which suffered a comparable expulsion of its people, who were gassed as well, but lacks the history of UN administration and the authority of a Security Council resolution promising a final status decision.

Russian President Putin invokes the Balkan example, suggesting that his interest in Crimea and eastern Ukraine derives from humanitarian concern to protect Russian-speakers. He claims to be doing nothing more than what NATO did for Kosovo. Others would suggest that Russia's provision of weapons and support to paramilitaries in Ukraine is a page out of Milošević's playbook, as is his exaggerated complaint about abuse of Russian-speakers and the consequent need for intervention to protect them. Milošević always claimed that he was simply protecting Serbs, even after having fueled with weapons, claims to victimhood, and ethnic hate speech the trouble they found themselves in. Russia is likewise not protecting Russian-speakers but rather generating pretexts for intervention and even, in Crimea, annexation.

The merits and demerits of no-fly zones, safe areas, humanitarian corridors, ethnic division, annexation, self-determination, and the like in Iraq, Syria, or Ukraine have nothing to do with their supposed success, and occasional real failure, in the Balkans. Context matters. 2018 is not 1995. Vladimir Putin's Russia-determined to defy the West, limit NATO expansion, and establish hegemony over Russian-speaking populations in neighboring states-is not Boris Yeltsin's Russia, which was prepared to collaborate with NATO. The United States of Barack Obama and Donald Trump, broke and exhausted after long and costly wars in Afghanistan and Iraq as well as many smaller engagements against agile and protean terrorists - is not the United States of Bill Clinton, riding a giant economic wave and unchallenged militarily worldwide.

The differences are stark. The 1990s were the unipolar moment. Today is the G-zero world. ${ }^{l}$ Not only is the unipolar moment over, but nothing has taken its place. The Balkans, geographically and culturally in Europe, is not the Middle East, where authoritarianism survived longer because it was not tied to Communism. Islam in the Balkans is mostly far more moderate than Islam in the Middle East, even if terrorists and their 
supporters have been discovered in Bosnia and Kosovo and inordinate numbers of foreign fighters have been recruited there.

There are, however, also valid parallels between the Balkans on the one hand and the Middle East and Ukraine on the other. Syria, Iraq, and a large part of North Africa share with most of the Balkans a history in the Ottoman Empire, as does part of southern Ukraine. That is relevant: the Ottomans ruled a multi-sectarian, multi-ethnic empire without homogenizing their populations, the way most European states tried to do, with greater and lesser degrees of success. The millet system of the Ottomans allowed different confessional groups to administer their own personal-status laws in distinct courts. Ethnic and sectarian diversity in Syria and Iraq is a legacy of that Ottoman heritage, just as in the Balkans. So too is the second-class treatment of non- "constituent" peoples, that is, those who are not responsible for forming the state. Linguistic diversity in Ukraine is a legacy of the Russian Empire and the Soviet Union, which failed in their efforts to extirpate Ukrainian.

There is another parallel: the Sunni/Shia divide in the Middle East is like the Catholic/Orthodox divide in the Balkans, insofar as it derives originally from a quarrel over who was the proper successor to a recognized leader. While there are today theological, organizational, clerical, and other differences as well, the root of the Sunni/Shia division is the succession to Muhammad. To make a long story short, Shia believe the caliph ("successor") should have been a family relation, specifically, Muhammad's cousin and son-in-law Ali; Sunni disagree and believe that Abu Bakr, a companion of the Prophet, was properly elected as his successor, as well as others who followed (including eventually Ali, who became the fourth caliph). Catholics respect as their religious authority the pope in Rome. Starting in the eleventh century, Orthodox Christians recognized the authority of their own "autocephalous" churches, which are not subordinate to the Roman pope.

But these parallels do not mean any of the approaches taken in 1995 to end the Bosnian War will necessarily work in Ukraine or Syria. A dysfunctional Dayton-style power-sharing arrangement would not be a good outcome in Kiev. There is no reason to believe Bashar al-Assad would allow it in Damascus, now that he appears to be winning Syria's seven-year war. Likewise, what worked for Kosovo would not be workable for the southeastern Ukrainian region of Donbas or for Iraqi Kurdistan, which lacks the internal cohesion required for independence and neighbors prepared to recognize it as a sovereign state. 
What might have counted from the Balkans experiences is not Dayton but rather the atrocities and abuses against civilians. "Responsibility to Protect" (R2P) is the UN-endorsed doctrine based on the Balkans and Rwanda tragedies that requires states to protect their populations and allows international intervention under limited circumstances when they do not. ${ }^{2}$ R2P cannot help the Syrians or the Ukrainians, because of differences between the United States and Russia in the UN Security Council. But it helped in Libya, where the Security Council authorized a NATO-led intervention in 2011 when Qaddafi threatened to slaughter the population of Benghazi. More recently, the Yezidis of northern Iraq owe their escape from the Sinjar Mountains to American airdrops of humanitarian supplies as well as air strikes against the Islamic State forces, authorized by Baghdad. States today are clearly obligated to protect their civilian populations. If they fail to do so, or cannot, other states can be licensed to intervene in ways that did not exist in Bosnia in 1995. That, more than "Dayton," is a legacy we should respect, but we failed to do so as Aleppo, eastern Ghouta, and southern Syria fell to Russian, Iranian, and Syrian onslaughts. We also failed to do so in Donetsk, Luhansk, and Crimea.

There are some other important lessons worth learning from the Balkans: leadership is important to starting, preventing, and ending wars; prevention can work, if undertaken early with adequate resources; ethnic partition likely will not; international contributions can be vital; neighborhood counts; power sharing and decentralization can help.

\section{Leaders Matter}

Leaders matter. The Balkan wars would not have happened as they did without Milošević's conversion to Serbian nationalism, based on the claim that Serbs were victims. "All Serbs in one country" promised protection, but it alarmed and excluded non-Serbs, who sought protection on territory they could call their own. Likewise, Iraq's Prime Minister Nouri al-Maliki and Syria's President Bashar al-Assad chose to govern in exclusionary ways that undermined their legitimacy with portions of their countries' populations, triggering sectarian passions and rebellion. Assad, who belongs to the Alawite minority, brutally cracked down on peaceful demonstrations in 2011, driving his opposition to take up arms. Maliki opened Iraq's door to the Islamic State when he tried to repress 
largely peaceful Sunni demonstrations using force in 2013. One of the first moves by the Ukrainian parliament after pro-Russian President Yanukovych fled was to pass a law denying official status to the Russian language. The law was blocked, but the resentment it generated helped separatists in eastern Ukraine to gain traction with the Donbas region's Russian-speaking population. Inclusion is a key to preserving state integrity. States that rely on mobilizing a part of their population based on identity necessarily exclude others and tend to fail. ${ }^{3}$ Inclusion, however, does not necessarily get you elected or keep you in power. Some leaders decide that appealing to only a portion of the population, and repressing the rest, is a better idea. The wars in the Balkans, Syria, Iraq, and Ukraine demonstrate the point.

Leadership matters in the opposition too. When Communism fell, ethnic nationalists in the Balkans were the best organized and equipped to take over. In much of the Middle East, the ideology of political Islam long prevailed among opposition forces. ${ }^{4}$ Once the Middle East autocracies began to crumble, Islamists were among the best organized and most united alternatives, not liberal democrats. Those who believe holy scripture is the word of God, and therefore the source of legitimacy and law, have a hard time with government of the people, by the people, and for the people. It should be no surprise that Islamist leadership that insists on sharia law is often intolerant of non-Muslims, non-believers, and liberal democrats. In the most extreme case, the Islamic State insurgency disdained its Shia counterparts, expelled them from territory it controlled, and sought to erase borders in the Middle East. Likewise, Putin and Russophiles in eastern Ukraine would have liked to restore the idea of "Novorossiya," which amounts to a claim that much of Ukraine rightfully belongs to Russia. That would require the expulsion of a lot of Ukrainians and the repression of any who resist. That is not likely in all of Ukraine, but it has already happened in Crimea and to some extent in Donbas. Exclusionary leadership has consequences.

It does not follow, however, that inclusionary ideology has good consequences. Assad's Alawite minority-controlled regime is rhetorically anti-sectarian and tolerant, but it is also autocratic and homicidal. It protects the majority Sunnis and minorities who support the regime, but not the Sunnis and minorities who do not. In more-democratic societies there is at least some chance that leaders will feel pressure to deliver on their ideological commitments. Assad feels none. 


\section{Prevention Can Work}

Prevention can work, if undertaken early with adequate resources. It did not in Bosnia, because the Europeans and the UN were unwilling and unable to mobilize the resources required. Their deployment of observers first and peacekeepers later was inadequate to make Belgrade and the Bosnian Serbs back down from their effort to create Greater Serbia. Even with American engagement, the same was true in Kosovo. ${ }^{5}$ The Macedonian case benefited from an explicitly preventive but still minimalist UN deployment. It worked because Serbia was not prepared to fight for Macedonia and therefore fewer resources were required. One can only wonder what might have been prevented had Syria welcomed an international deployment to help it transition to democracy, rather than chasing the Arab League observers out in 2012. Or if the United States and Europe had been prepared to intervene early to protect civilians. The failure to intervene in August 2013 against Assad for use of chemical weapons is often cited, but the one-off air strikes contemplated then would not have been sufficient to deter Damascus, and it was arguably already too late. Organization for Security and Co-operation in Europe (OSCE) observers in Ukraine are still struggling to monitor cease-fire agreements, as European observers did in Bosnia in the early 1990s, but they are unable to guarantee compliance. Successful prevention requires the willing cooperation of potentially warring parties and international guarantees backed by potential use of force. That is not always available, but when it is it can save lives and prevent disaster.

The top priority in postwar reconstruction efforts is to prevent a return to violence. Dayton implementation after 1995 and the UN protectorate in Kosovo after 1999 thus amounted to largely successful conflict prevention, albeit less formally constituted than in Macedonia. As we have seen in Libya, leaving a war-torn country to its own devices, even if that is what the country's leadership prefers, can lead to catastrophic consequences. But military interventions in Afghanistan and Iraq were unsatisfactory in their outcomes, despite the postwar application of massive military and civilian resources. Conflict prevention through international intervention postwar also works best when it is welcomed, as it was in Bosnia and Kosovo, not resisted, as in Afghanistan and Iraq. Extremist resistance is particularly difficult to handle, since with them a negotiated outcome is often not possible. ${ }^{6}$ 
The jury is still out in Ukraine. Doubting its capability to pursue two simultaneous wars, Russia toned down the war in the Donbas region in September 2015, to enable its military intervention in Syria. Something like a mutually hurting stalemate may be emerging in Ukraine, with neither the Russian nor the Ukrainian forces seeing much to be gained by continuing the fight. If the "Normandy" powers (France, Germany, Russia, and Ukraine) entrusted with the search for a negotiated solution can find a political way out, or even just freeze the current situation, Ukraine might be able to avoid the kind of wider war that tore Bosnia to shreds and threatened disaster in Kosovo. But it is also still possible that the relative lull in Ukraine will be temporary, presaging an intensified military effort by Moscow and a political effort to prevent Ukraine from tying itself more closely to the EU. The OSCE is walking an unsteady tightrope.

In the Middle East, prevention had its moment in Yemen in late 2011, when the Gulf Cooperation Council managed to get President Ali Abdullah Saleh to leave power in favor of his vice-president, the first step in a multi-phase transition that culminated in a national dialogue in 2013-2014. But the national dialogue failed to resolve key issues concerning the architecture of the state, especially with respect to the northern Houthis as well as the south. With no international force deployed to protect the peace process, a Houthi offensive in 2015 chased the transitional president, whose term had expired, from Sanaa and initiated a civil war that drew in Saudi Arabia and the United Arab Emirates in support of the internationally recognized government as well as Iranian support for the Houthis. Prevention is desirable and relatively cheap, and often worth a try, but it does not always work, especially in the absence of strong international guarantees. Who can provide such guarantees in Yemen once the fighting is over is not clear, making it difficult to negotiate an end to the now internationalized civil war.

\section{Ethnic Partition Likely Will Not Work}

A third lesson is about partition, especially redrawing of territorial lines to accommodate ethnic differences. All the current borders of the Balkan states remain where they were in Socialist Yugoslavia. Only their status has been changed, from internal boundaries to international borders. Even in Kosovo, whose population is about 90\% Albanian, the international community has so far refused to allow the four northern 
municipalities, which are contiguous with Serbia and three of which had majority-Serb populations even before the 1999 war, to opt out and rejoin Serbia, despite their relatively recent addition to Kosovo. The Kosovo/Serbia "border"- or for those who do not recognize Kosovo's independence, "boundary" - has not moved.

In the Middle East the international borders are also relatively recent, having been established in the 1920s. They are often attributed to Mark Sykes and François Georges-Picot, British and French diplomats, respectively, but that is not right. Mosul, originally slated for the French colonial mandate under the 1916 Sykes-Picot Agreement and therefore in what we now call Syria, was ceded in 1924 to the British, who already had troops there. The Islamic State, which claimed to be destroying the Sykes-Picot borders, ironically restored them when it absorbed large parts of Iraq's Anbar, Ninewa, and Salaheddin Provinces into a territory they controlled along with eastern Syria. That is how Sykes and Picot had drawn the lines originally. ${ }^{7}$

The borders of Ukraine are even more recent: the Soviet Union transferred Crimea to Kiev's authority only in 1954. Ukraine had emerged as an independent state for the first time, but only briefly, in 1918 . It lost part of its territory to Poland and was incorporated into the Soviet Union in 1922.

The question is whether redrawing some of these relatively recent borders to accommodate ethnic or sectarian differences might help to stabilize chronically unstable regions. That is a good question, one ethnic nationalists never tire of asking. The answer is a qualified no. Even if everyone in a region can agree that the borders are arbitrary and should be changed, experience suggests they rarely agree on where they should be redrawn. Czechoslovakia was divided in its 1993 "velvet divorce" peacefully along an agreed preexisting line. In 2011, Sudan was also divided by agreement, but the lines were not so clear. The predictable result was violence focused initially on the Abyei area, where the line was not agreed.

That is the rule. Bosnia's Serbs, Croats, and Bosniaks were unable to agree on their lines of division, which is why they fought. The VanceOwen plan for drawing ethnic boundaries in Bosnia contributed to the war, not to its solution. ${ }^{8}$ Macedonia's ethnic Albanians and ethnic Macedonians know perfectly well that they cannot agree on division of the country. The city with the largest Albanian population in Macedonia is the capital. Any attempt to divide it would mean war. Kosovo's Albanians have until recently insisted on reintegration of the country's 
Serbian-majority north not because they are anxious to govern Serbs but because they know partition would call into question their borders with Albania and Macedonia, which Washington and Brussels would not allow. If you open the question of borders in one country, you are bound to cause questioning of borders in other countries in the region and possibly beyond. That is as true of Syria and Iraq in the Middle East as it is of Bosnia and Kosovo in the Balkans.

Iraqi Kurdistan has what many consider a compelling case for independence, which would mean partition of Iraq. Saddam Hussein brutally mistreated the Kurds, chasing them from their homes and even out of the country. He also gassed tens of thousands during the 1986-1989 Anfal campaign. The Kurds have largely governed themselves since 1991, when the United States, Britain, and France imposed a no-fly zone over their territory. Kurdistan won a large measure of autonomy in the 2005 Iraqi constitution, but the relationship between Baghdad and Erbil has been rocky since. The Kurdistan Regional Government (KRG) claims it has not received all the oil revenue it is entitled to, that it has had to defend its own territory from the Islamic State without needed support from Baghdad, and that it faces demands from its population, many of whom no longer speak fluent Arabic, for independence. The KRG claims to be democratic and to treat minorities well. Why should it not be independent?

The geopolitical circumstances are not favorable. While Iraqi Kurdistan has vastly improved its relations with Ankara, large parts of what is now eastern Turkey were slated at the end of World War I to become part of an independent Kurdish state. Turkey does not want to see independence for its southern neighbor while it represses a violent Kurdish rebellion on its own territory, for fear of the irredentist consequences. Iranians feel even more strongly on this issue: fighting frequently flares in Eastern Kurdistan, which is a province of the Islamic Republic. Iran's population is not much more than 60\% Persian. Tehran fears the Kurds will not be the only ones looking to get out. Baloch have been rebelling since 2004 .

Iraqi Kurds naturally look to the Americans for support. Washington was vital to their survival in the 1990s. The Kurds supported the 2003 U.S. invasion of Iraq and happily hosted American forces. The KRG has welcomed Iraqis of varied sects and ethnicities displaced by ISIS, against whom its Peshmerga fought effectively, and maintains friendly relations with the United States, even welcoming American oil investment and until recently admitting Americans without the visas the 
Baghdad government requires. Kurdish friends ask plaintively: Don't the Americans want a friendly ally in the Middle East? One with at least a nominal commitment to multiethnic democracy?

Washington might, but it has global concerns, which include protecting its equities in Baghdad and maintaining the sovereignty and territorial integrity of Georgia, Ukraine, and Moldova, all of which have Russian-supported territories wanting to secede. Independence for Kurdistan would open the proverbial Pandora's box, strengthening Putin's arguments and undermining the international consensus that has formed against independence for South Ossetia and Abkhazia, the annexation of Crimea, and the rebellion in Donetsk and Luhansk, as well as the aspirations of Moldova's Transnistria. China is no less opposed to Kurdistan independence than the Americans, for fear of the implications for Tibet. Geopolitics are not sympathetic to Kurdish aspirations.

Inside Iraq, there are other issues. Kurdistan's main political parties all agree on independence as their goal, but none are willing to see the others get credit for it. Former Kurdistan Regional President Mustafa Barzani locked his opposition out of parliament and was none too gentle with those in the press and civil society who tried to buck his authority. The boundaries of Iraqi Kurdistan are not agreed. While the KRG seized the so-called disputed territories during its offensive against the Islamic State in 2014, Baghdad did not agree that they belong within Kurdistan. The KRG offered to conduct referenda in these territories on whether they would want to join with Kurdistan, fulfilling a provision of the Iraqi constitution. But doing that in the absence of international supervision and with the KRG in control was not going to convince Baghdad that a free choice had been made.

At oil prices around $\$ 50$ per barrel in 2017 , the KRG was nowhere near having the financial resources to be independent. Independence would have left Kurdistan even worse off. It is an oil rentier state, despite its hopes for a more diversified economy. Oil prices in the future will have a hard time going over $\$ 80$ per barrel for a sustained period, because above that level massive quantities of unconventionally produced oil and gas (as well as other alternatives) will come online. The KRG needs closer to $\$ 100$ per barrel to meet its financial requirements with oil production well above current levels.

Barzani nevertheless proceeded with an independence referendum in September 2017, which predictably won approval by a wide margin. He claimed it would be prelude to renegotiation of the relationship with 
Baghdad, not necessarily a one-way street to independence. Anyone who knows Kurds would doubt that after voting independence they would return to the negotiating table to accept some sort of confederal arrangement to stay nominally inside Iraq. An independence referendum was far more likely to trigger still another violent conflict, in which Arabs (both Sunni and Shia) would fight Kurds to determine the borders they had failed to agree on for more than a decade.

That is what happened, though on a relatively small scale. Iraqi Prime Minister Haider al-Abadi, fresh from victory over the Islamic State, used his battle-hardened forces to retake most of the disputed territories, with some mostly passive help from Barzani's political rivals. The redrawing of sovereign borders in the Middle East suffered a resounding setback.

Partition has also been proposed for Syria. Henri Barkey, a distinguished scholar of the Middle East, proposed ethnic/sectarian division of the country into three parts: Alawite and Christian in the west, Kurdish in the north, and Sunni in the center. ${ }^{9}$ The trouble is that the population is not distributed that way. The Alawites have never been a majority in the main population centers of the west, to which many Sunnis have fled because of the war. Kurdish populations in the north are mixed with Arabs. Christians and other minorities are embedded among the Sunnis. Many Alawites live in Damascus. Drawing ethnic and sectarian lines would lead to a bloodbath in Syria as each group seeks to establish a majority in its designated area.

Crimea represents a possible exception to the rule. Its border is not in doubt, and its transfer to Ukraine was recent. President Trump has indicated some sympathy for the Russian annexation of a territory where most people speak Russian. Much of Crimea's population, though not the minority Tatars, appeared to welcome the peninsula's transfer back to Russian rule, though only time will tell whether that attitude is permanent. The March 2014 referendum was not free or fair. Conducted under Russian military occupation, it failed to offer an option to remain with Crimea's relatively autonomous status within Ukraine. Tens of thousands of Crimean Tatars and Ukrainians have been chased from their homes. Both the UN General Assembly and Security Council overwhelmingly voted their disapproval, but General Assembly resolutions are not binding. ${ }^{10}$ Russia vetoed Security Council action, claiming that Kosovo set a precedent for what was done with Crimea.

The analogy is false. Crimea had no UN peacekeeping forces or UN administration. It was seized by force, not occupied in accordance with a 
Security Council resolution. Only a handful of countries have recognized its annexation. It is costing Moscow a bundle. The Americans and Europeans are refusing to accept the annexation, as they did with the Baltic states when incorporated into the Soviet Union at the end of World War II. ${ }^{11}$ They hope some future Russian government will implement a negotiated settlement for Crimea, one that returns it to Ukrainian sovereignty but with a great deal of autonomy. The Russians hope for the inverse: American recognition of the annexation of Crimea (and perhaps also the "independence" of South Ossetia and Abkhazia) in exchange for Russian acceptance of Kosovo's independence.

In the Middle East, Pandora's box now contains oil and gas, which intensifies conflicts over territory. The Iraqi city of Kirkuk has long been disputed among Kurds, Arabs, and Turkmen. Its oil and gas production raises the stakes. The Syrian government wants to regain control of the country's eastern oil and gas fields, now in the hands of the Syrian Democratic Forces whom the Americans backed in the battles against the Islamic State in eastern Syria. Fuel and hydrocarbon revenue could be critical in the postwar period. Likewise, Iraq's Sunnis are not going to allow Iraq's south to walk off with the country's massive reserves. Partition of Iraq or Syria is a bad idea because it would cause more war, not end it. In the Middle East and Ukraine as much as in the Balkans, attempts at ethnoterritorial partition are bound to generate atrocities and other human rights abuses.

\section{Neighborhood CounTs}

Neighborhood is a key factor in determining the outcome of war. ${ }^{12}$ The Balkans lies between Greece and the rest of the EU. It is not surprising that the region eventually found a better trajectory than the one it traced in the 1990s, even if it is now struggling to maintain its European ambitions. Though historians and geographers are fond of the Mediterranean basin as a unifying theme for the countries of its littoral, Europe and the Middle East have not been on the same wavelength for a millennium. European efforts to promote trade and investment with the Middle East and to export liberal values have failed. ${ }^{13}$ Only Turkey among Middle Eastern countries once enjoyed the theoretical prospect of eventual EU membership, but President Erdoğan's autocratic impulses are now all too obvious. The Middle East is a decidedly bad neighborhood if you are looking for models of good governance and rule of law. 
Iraqi Kurdistan is a possible exception. It has pretensions to Western values, but its duopoly has been less than liberal when it comes to freedom of expression, and its courts fall far short of independence. Kurdistan has had to worry more about security issues than reform. It is also plagued with the endemic corruption associated with oil revenues, whose disposition has been far from transparent. If your nearest neighbors are Iran, Arab Iraq, Syria, and southeastern Turkey (where repression of Kurds has been strong for decades), liberal democracy is not the first governance system that comes to mind.

Ukraine counts EU members Romania and Poland among its neighbors, in addition to Russia and Belarus. The predictable result is ambiguity. While many Ukrainians in the western part of the country prefer to follow a European model, the east is closely tied to Russia. Kiev, which counts Brussels among its key supporters and seeks eventual EU membership, has been slow to institute reforms, but the pressure is strong. Ukraine is fortunate to have the Brussels pole exerting its attractive force.

The Middle East lacks this teleological drive. There is no magnet pulling the countries of the failed 2011 Arab uprisings (Egypt, Yemen, Syria, and Libya) in a more democratic direction or offering a state paradigm based on rule of secular law. The only model of moderate political reform in the Arab Middle East is Tunisia, which is too small, too far removed from the Middle East's center of gravity, and too close to the starting gate to pull others in its barely perceptible wake. There are more models that point in the monarchical and autocratic directions. The kings of Jordan and Morocco have instituted modest reforms, but they remain illiberal, even if nominally constitutional at best. The Gulf monarchies, especially Saudi Arabia, the United Arab Emirates, and Bahrain, are more inclined to autocracy, even when pursuing reforms. Saudi Arabia and the UAE have also been willing to use their deep pockets of oil revenue to sponsor secular autocrats in other countries, especially Egypt and Jordan, while Qatar has used its vast natural gas revenue to fund the Muslim Brotherhood and other Islamists.

The lack of a nearby, attractive, pluralistic, democratic model, current or historical, is profoundly important. ${ }^{14}$ While Muslims in Indonesia and elsewhere have come to enjoy democracy, in the Middle East its roots are shallow. Association with military autocracy has tainted secularism. The courts that administer law in secular Middle Eastern autocracies have been loyal tools of repression. The result is wide and apparently growing appeal of sharia, Islamic jurisprudence. The Islamic State's 
brutal caliphate has far more resonance in the Middle East than liberal democracy.

The Middle East needs a set of norms, like those the OSCE promulgated starting with the 1975 Helsinki Final Act, which set out agreed principles and attempt to channel competition into peaceful rivalry, reducing the incentive states feel to repress minorities, even when the states are autocratic. ${ }^{15}$ If Iran and Saudi Arabia feared each other less, they would do less to repress the minority Sunni and Shia who inhabit their respective territories, as well as those of their neighbors. If they had an organization like the OSCE, or even the less norm-based Association of Southeast Asian Nations, managing the conflicts that do arise would be far more likely to keep the peace. Peaceful coexistence as a regional goal is a low bar, but it would represent a distinct improvement over the current situation. ${ }^{16}$

\section{International Contributions Can Be Vital}

Eventually, foreign military intervention ended the slaughter in the Balkans. It worked in Libya when Qaddafi threatened mass atrocities in Benghazi. Libya's deterioration from late 2012 onward should not hide the success of the NATO-led air campaign. ${ }^{17}$ American airpower was vital in helping Iraqi as well as Syrian Kurdish-led forces turn the tide against the Islamic State and its atrocities from 2015 onward.

The United States hesitated, however, to intervene against Assad in Syria. The CNN effect has faded, because of the wide availability of atrocity photographs and videos. We are inured. Tired of being the world's policeman, Washington refused even to act as its fireman, putting out a conflagration that caused massive refugee flows to Turkey, Lebanon, Jordan, and even Europe. Russia has been bolder: it massed troops on Ukraine's border to slow Kiev's advance into Donbas, then invaded southeastern Ukraine in late 2014 to protect the separatists when Kiev ignored the threat. In 2015, Russia established an air base in Syria, from which it has bombed mainly moderate opposition forces to prop up President Assad. This is ironic: a Russia that portrays itself as a principled advocate of national sovereignty opposed to anti-constitutional intervention in Syria is breaching both sovereignty and constitutionality in Ukraine, not many kilometers away.

Foreign intervention does not always mean military force. Economic and financial sanctions are far more common. They rarely work quickly 
when imposed. But relief from sanctions as part of negotiated political settlement can be a powerful diplomatic tool. Milošević negotiated long and hard for relief from sanctions, which were suspended in return for his adherence to the Dayton agreements. Putin has used the imposition of sanctions to rally Russians against the West. But he will no doubt someday be looking for relief from them in any settlement of the Ukraine conflict. Draconian UN sanctions on Iran brought Tehran to the bargaining table, but it was only relief from them that enabled the now-abandoned nuclear deal to be concluded. Relief from sanctions will no doubt be important in the negotiation of any political settlements in Syria as well as Yemen.

International contributions are not limited to military force and sanctions, which are blunt instruments. Diplomacy matters. It is far easier between two parties than among three or more. War in Bosnia was three-sided: the Croat Defense Council fought the Bosnian Army in 1992 and 1993 even as both fought together against the Bosnian Serb Army. The United States provided vital support to the UN in ending the fighting between the Croats and the Bosnian Army, thus reducing a three-party problem to a far easier, if still complex, two-party conflict at Dayton. In Iraq the fight against the Islamic State was mainly a two-party conflict, with Iraqi Kurdistan, Baghdad's various forces (including Iranian-supported militias), and the Americans in coalition against the Islamic State. Ukraine is mainly a two-party conflict, between Kiev and secessionists in the Donbas.

In Syria it is hard even to count the number of different parties involved: the government and its allied militias, Iran and its allied militias, Russia and its allied militias, Turkey and its allied militias, the Israelis, the Americans and allied European forces, as well as Arab, Kurdish, and secular militias, non-jihadi Islamist forces, the Islamic State, and Al Qaeda. The geometry of the relationships among them is not only complex; it is also variable. While the Russians have had some success in negotiating de-escalation zones that lead to surrenders, simplification of the equation is needed before negotiating a country-wide solution.

International guarantees of peace implementation are a particularly important factor in negotiating an end to war. ${ }^{18}$ The Americans and Europeans made it clear at Dayton that they would ensure implementation of any agreement reached there. The UN, supported by a NATO-led force, was committed, with Security Council support, to implementation of Resolution 1244, which ended the Kosovo War. 
In Ukraine there is some hope that UN peacekeepers might be deployed in the east to guarantee a peace agreement, if one is reached. But who could provide guarantees in Syria? At this point it is only the Russians and Iranians who would be willing, and they are committed to keeping Assad in power. The peace he imposes will seek to ensure his own security and hold on a "fierce" state, with the goal of restoring autocratic political and economic control. ${ }^{19}$

How a war ends obviously affects what happens thereafter, but not only in the expected ways. A flawed Dayton agreement froze the conflict in Bosnia and made it a less than fully functional state but still allowed Croatia to move in a more European direction. An equally flawed UN Security Council resolution ended the Kosovo war with ambiguity about its status but nevertheless enabled Serbia to begin to shed Milošević's autocracy and move toward Europe. Assad's fierce state may prove less resilient than he would like and less able to control parts of the country. The failure of the United States to end the wars in Afghanistan and Iraq with a definitive document marking the end of hostilities left the door open to continued insurgencies. It was a mistake not to insist that some Taliban commander or Iraqi army general sit at a table and sign on the dotted line. This is far more important for postwar developments than the more noted failure to declare war. ${ }^{20}$

\section{Power Sharing and Decentralization Can Help}

The Balkan wars of the 1990s, like the Arab uprisings of 2011 and the insurgency in Ukraine, were struggles over power and how it should be distributed. Power sharing at the national level has been an important part of the solution throughout the Balkans. Bosnia has rigid constitutional arrangements, imposed at Dayton, that require power sharing and make the country difficult to govern. Others have come to it more organically and less rigidly, but it now exists in one form or another throughout much of former Yugoslavia. Also important has been decentralization, which allows minorities to govern in local areas where they are in the majority. Municipal and provincial councils provide opportunities to share power that would be difficult to realize at the national level. They also provide opportunities for patronage that can be useful in pacifying minorities. The Minsk II agreement for Ukraine, if ever implemented, will provide ample opportunities for decentralized governance in the rebellious parts of Ukraine. 
In the Middle East, only Iraq, Tunisia, and Morocco have really tried serious power sharing at the national level. It worked, with hiccups, in Tunisia during the transition to a new constitution. It is working in Morocco as well, though the king remains in charge while sharing power over non-security issues with an Islamist-led government. In Iraq, power sharing among Shia, Sunni, and Kurds has been less successful. Their squabbling paralyzed Iraq during much of the prime ministry of Nouri al-Maliki, but it is hard to see how Iraq could be governed today without power sharing.

What has worked better in Iraq than national-level power sharing is decentralization. Power devolved to the KRG and to the Shia provinces has enabled those areas to continue reasonably stable governance even as the Islamic State took over the Sunni west and north. Decentralized democracy is a messy system but can be far less fragile than centralized autocracy, which depends for its survival on a Bashar al-Assad, Saddam Hussein, or Muammar Qaddafi. If Libya is to survive as a single state, it will need to devolve power to its regions and municipalities, which even today continue to function despite the national and regional instability. The same is true of troubled Yemen. Neither the Houthis nor South Yemen is likely to return to rule from Sanaa. Inclusion and empowerment, so important to stable governance, begin at the local level, where it is often harder to define issues in purely sectarian or ethnic terms. Filling the potholes and providing water are service issues, not identity ones.

\section{Conclusion}

More than twenty-three years will have passed since Dayton when you read this book. Rarely during those years were people in the Balkans optimistic about the future. The major Balkan protagonists-Bosniaks, Croats, Serbs, Albanians, and Macedonians-all feel unsatisfied. They complain that their states are corrupt and dysfunctional, their adversaries unjustly rewarded, their international friends insufficiently supportive. The same is true in the Middle East and Ukraine. Pessimism is rife. Since the outbreak of the Arab uprisings in early 2011 things seem only to have gotten more complicated and difficult. In Ukraine, Russia continues its occupation of Crimea and parts of the southeast.

The election of Donald Trump casts a long shadow on the Balkans, the Middle East, and Ukraine. The president admires Putin's leadership style, likes most autocrats, and sympathizes with ethnic nationalism both 
at home and abroad. His former campaign aides are busily marketing their services to Balkan ethno-nationalists. ${ }^{21}$ American support for liberal democracy, free trade, and open investment has weakened. Some think Trump aims to destroy the West. ${ }^{22}$ The president disdains international norms and views the world as disordered, hostile, and chaotic. That is a self-fulfilling prophecy, since the United States has been one of the key forces in sustaining the post-World War II international order. Ignoring this vital role, Trump puts his understanding of American interests first. He shows little interest in American ideals.

This attitude could have dramatic repercussions not only in the Balkans but also in Ukraine and the Middle East. Would-be autocrats in both regions are enjoying reduced pressures for democracy, rule of law, human rights, and open economies. While the State Department has pronounced the United States opposed to the Russian annexation of Crimea, it will not be surprising if the president still leans toward ethnic division in Ukraine. The administration opposed Iraqi Kurdistan's independence, but so late in the game that the referendum could not be blocked. Even serious consideration of partition anywhere in the Balkans, the Middle East, or Ukraine could trigger partition pushes elsewhere. Kosovo, Macedonia, Bosnia, and even Serbia could see ethnoterritorial ambitions reignited in ways that would be difficult to contain. Kurdish aspirations could put Turkey and Iran at risk. Iraq, Syria, Yemen, and Libya would also find the centrifugal forces their civil wars have already unleashed strengthened.

What the Balkans, the Middle East, and Ukraine need are principled commitments by their own politicians to move in the democratic and free-market direction. This unity of purpose will require eschewing ethno-sectarian appeals and partition, looking for ways to share power and decentralize to make governance more inclusive, blocking theft of state assets as well as other forms of corruption, seeking international assistance and guarantees to prevent conflict, and searching for models and helpful neighbors wherever they may be found. These are not difficult remedies, but they require thoughtful leadership, assiduous pursuit, and long-term perspectives.

Clarity about objectives is particularly important. If you know the right direction and keep moving, however slowly, you make progress. That is the best news from the Balkans. It would also be good news for Ukraine and the Middle East, if ever they can find a compass and begin the long, slow slog to more democratic, prosperous, and secure outcomes. 


\section{Notes}

1. Ian Bremmer, Every Nation for Itself: Winners and Losers in a G-Zero World (London: Portfolio, 2013).

2. United Nations Office on Genocide Prevention and the Responsibility to Protect, "Responsibility to Protect," http://www.un.org/en/genocideprevention/about-responsibility-to-protect.html.

3. Inclusion is the common theme of Daron Acemoglu and James A. Robinson, Why Nations Fail: The Origins of Power, Prosperity, and Poverty (New York: Crown, 2012); World Bank Group and United Nations, Pathways for Peace: Inclusive Approaches for Preventing Violent Conflict (Washington, DC: World Bank, 2018), https://openknowledge.worldbank.org/handle/10986/28337; Charles Call, Why Peace Fails: The Causes and Prevention of Civil War Recurrence (Washington, DC: Georgetown University Press, 2012); and Andreas Wimmer, Nation Building: Why Some Countries Come Together While Others Fall Apart (Princeton: Princeton University Press, 2018).

4. Shadi Hamid, Temptations of Power: Islamists and Illiberal Democracy in a New Middle East (New York: Oxford University Press, 2014).

5. For the multiple prevention failures in former Yugoslavia, see I. William Zartman, Cowardly Lions: Missed Opportunities to Prevent Deadly Conflict and State Collapse (Boulder, CO: Lynne Rienner, 2005), 137-80.

6. Barbara F. Walter, "The New New Civil Wars," Annual Review of Political Science, no. 20 (2017): 469-86.

7. Sara Pursley, “'Lines Drawn on an Empty Map': Iraq's Borders and the Legend of the Artificial State (Part 1)," Jadaliyya, June 2, 2015, http:// www.jadaliyya.com/Details/32140/\%60Lines-Drawn-on-an-EmptyMap\%60-Iraq's-Borders-and-the-Legend-of-the-Artificial-State-Part-1.

8. Matjaž Klemenčič, "The International Community and the FRY/ Belligerents, 1989-1997," in Confronting the Yugoslav Controversies: A Scholars' Initiative, ed. Charles W. Ingrao and Thomas A. Emmert (West Lafayette, IN: Purdue University Press, 2009), 153-98.

9. Henri J. Barkey, "A U.S. Blueprint for Syria," The American Interest, January 27, 2016, https://www.the-american-interest.com/2016/01/ 27 /a-u-s-blueprint-for-syria/.

10. "Resolution Adopted by the General Assembly on 27 March 2014," https://undocs.org/A/RES/68/262.

11. This position has been formalized by the State Department (not, however, by the White House); see Secretary of State Michael R. Pompeo, "Crimea Statement," July 25, 2018, https://www.state.gov/secretary/ remarks/2018/07/284508.htm.

12. Christoph Zürcher, Carrie Manning, Kristie D. Evenson, Rachel Hayman, Sarah Riese, and Nora Roehner, "Neighborhood," in Costly Democracy: 
Peacebuilding and Democratization after War (Stanford: Stanford University Press, 2013), 112-30.

13. Aylin Ünver Noi, The Euro-Mediterranean Partnership and the Broader Middle East and North Africa Initiative: Competing or Complementary Projects? (Lanham, MD: University Press of America, 2011).

14. "The Tragedy of the Arabs," Economist, July 5, 2014, https://www.economist.com/leaders $/ 2014 / 07 / 05 /$ the-tragedy-of-the-arabs.

15. Caveat emptor: I am affiliated with a Middle East Dialogue that aims to develop such a set of principles; see "The Baghdad Declaration: Good Neighborhood Principles for the Middle East," Middle East Institute, February 2018, http://www.mei.edu/content/baghdad-declaration-goodneighborhood-principles-middle-east. Notably, the first principle includes territorial integrity of the existing states.

16. Paul Salem, "The Road Less Traveled: Potential Pathways from Disorder to Order in the Middle East," in From Chaos to Cooperation: Toward Regional Order in the Middle East, ed. Ross Harrison and Paul Salem (Washington, DC: Middle East Institute, 2017), 1-14.

17. Frederic Wehrey, The Burning Shores: Inside the Battle for the New Libya (New York: Farrar, Straus and Giroux, 2018).

18. Barbara F. Walter, Committing to Peace: The Successful Settlement of Civil Wars (Princeton: Princeton University Press, 2002).

19. Steven Heydemann, "Beyond Fragility: Syria and the Challenges of Reconstruction in Fierce States," Brookings, June 2018, https://www. brookings.edu/wp-content/uploads/2018/06/FP_20180626_beyond_ fragility.pdf.

20. Tanisha M. Fazal, "Why States No Longer Declare War," Security Studies 21, no. 4 (2012): 557-93, https://www.tandfonline.com/doi/abs/10.1 $080 / 09636412.2012 .734227$.

21. Casey Michel, "Ex-Trump Campaign Officials Are Now Appearing with Pro-Moscow Separatist Leaders," ThinkProgress, June 15, 2018, https://thinkprogress.org/these-trump-campaign-officials-are-causingtrouble-in-bosnia-2873f3e205c4/.

22. David Leonhardt, "Trump Tries to Destroy the West," New York Times, June 10, 2018, https://www.nytimes.com/2018/06/10/opinion/g7trump-quebec-trudeau.html. 
Open Access This chapter is distributed under the terms of the Creative Commons Attribution 4.0 International License (http://creativecommons.org/ licenses/by/4.0/), which permits use, duplication, adaptation, distribution and reproduction in any medium or format, as long as you give appropriate credit to the original author(s) and the source, a link is provided to the Creative Commons license and any changes made are indicated.

The images or other third party material in this chapter are included in the work's Creative Commons license, unless indicated otherwise in the credit line; if such material is not included in the work's Creative Commons license and the respective action is not permitted by statutory regulation, users will need to obtain permission from the license holder to duplicate, adapt or reproduce the material.

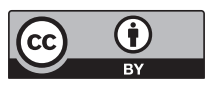

